\title{
Determinan Luas Pengungkapan Kompensasi Manajemen Kunci
}

\author{
Fransiska Dona Mayresa \\ Universitas Katolik Soegijapranata \\ fransiskadmayresa@gmail.com
}

\begin{abstract}
This study aims to determine the effect of institutional share ownership, audit quality, frequency of audit committee meetings and remuneration committees to the extent of disclosure of key management compensation in the financial statements.

The population used in this study is the financial statements of all companies listed on the Indonesia Stock Exchange (IDX) period of 2012-2016. The method used for sample selection in this study is by purposive sampling method. To test hypothesis in this research the analysis that can be used is multiple linear regression analysis. The results show that institutional ownership, audit quality, frequency of audit committee meeting affect the disclosure of management compensation.,
\end{abstract}

Keywords: institutuional ownership, audit quality, remuneration committee, disclosure

\begin{abstract}
Abstrak
Penelitian ini bertujuan untuk menguji pengaruh kepemilikan saham institusional, kualitas audit, frekuensi pertemuan komite audit dan komite remunerasi terhadap luas pengungkapan kompensasi manajemen kunci di laporan keuangan.

Populasi yang digunakan dalam penelitian ini adalah laporan keuangan dari semua perusahaan yang terdaftar di Bursa Efek Indonesia (BEI) periode tahun 2012-2016. Metode yang digunakan untuk pemilihan sampel dalam penelitian ini adalah dengan metode purposive sampling. Untuk melakukan uji hipotesis dalam penelitian ini analisis yang dapat digunakan adalah analisis regresi linear berganda.

Kesimpulan dari penelitian ini adalah kepemilikan saham institusional berpengaruh terhadap luas pengungkapan kompensasi manajemen kunci, kualitas audit berpengaruh terhadap luas pengungkapan kompensasi manajemen kunci, frekuensi pertemuan komite audit berpengaruh terhadap luas pengungkapan kompensasi manajemen kunci, komite remunerasi berpengaruh terhadap luas pengungkapan kompensasi manajemen kunci.
\end{abstract}

Kata kunci: Kepemilikan Institusional, Kualitas Audit, Komite Remunerasi, Pengungkapan Kompensasi Manajemen Kunci.

\section{PENDAHULUAN}

PSAK 24 (revisi 2004) menyebutkan bahwa kompensasi merupakan seluruh imbalan kerja (sebagaimana didefinisikan termasuk imbalan kerja yang berlaku pada PSAK 53 tentang Akuntansi Pembayaran Berbasis Saham). Manajemen kunci adalah orang-orang yang mempunyai kewenangan dan tanggung jawab untuk merencanakan memimpin kewenangan dan tanggung jawab untuk merencanakan, memimpin dan mengendalikan aktivitas entitas, 
secara langsung atau tidak langsung, termasuk direktur dan komisaris (baik eksekutif maupun tidak, dari entitas dan tidak dari entitas). Sementara, PSAK No. 7 (revisi 2010) mewajibkan perusahaan untuk mengungkapkan jumlah kompensasi personil manajemen kunci di laporan keuangan. Namun tidak semua perusahaan mematuhinya karena pengungkapan kompensasi manajemen kunci dianggap sebagai informasi privat yang dapat dimanfaaatkan pihak lain untuk tujuan pribadi.

Berbagai penelitian empiris telah dilakukan untuk mengidentifikasi determinan luas pengungkapan manajemen kunci. Chzema (2008) menemukan kepemilikan institusional berpengaruhi positif terhadap pengungkapan kompemsasi. Sebaliknya, Astasari dan Nugrahanti (2014) menunjukkan bahwa konsentrasi kepemilikan institusional berpengaruh negatif terhadap luas. pengungkapan manajemen kunci. Penelitian lain juga telah menunjukkan adanya hubungan antara efektivitas komite yang ada dalam dewan dan pengungkapan keuangan. Penelitian sebelumnya telah menunjukkan bahwa karakteristik komite (yaitu ukuran, independensi, keahlian anggota dan frekuensi rapat mereka) dan komite remunerasi menentukan keefektifannya. Penelitian di Bursa Efek Indonesia juga masih menunjukkan tidak konsisten. Penelitian Akmyga dan Mita (2015) menunjukkan bahwa frekuensi pertemuan komite audit berpengaruh positif terhadap pengungkapan kompensasi manajemen kunci.

Penelitian ini menguji kembali faktor-faktor yang mempengaruhi pengungkapan manajemen kunci. Hal ini didorong oleh temuan-temuan sebelumnya yang tidak konsisten. Fokus penelitian ini terutama pada mekanisme GCG yang ada di dalam perusahaan dan fungsi pengawasan oleh pemegang saham institusi. Secara spesifik, variabel independen yang akan diuji adalah kepemilikan saham institusional, kualitas audit, frekuensi pertemuan komite audit dan komite remunerasi.

\section{TINJAUAN LITERATUR DAN PERUMUSAN HIPOTESIS}

\section{Teori Agensi (agency theory)}

Teori agensi menjelaskan tentang hubungan keagenan timbul ketika salah satu pihak (prinsipal) menyewa pihak lain (agen) untuk melakukan beberapa jasa untuk kepentingannya yang melibatkan pendelegasian beberapa otoritas pembuatan keputusan kepada agen (Jensen dan Mecking, 1976). Di dalam teori agensi dijelaskan mengenai asimetri informasi dimana manajer sebagai pengelola perusahaan memiliki informasi lebih baik dan komplit daripada pemilik atau pemegang saham. Hal ini dapat memberikan kesempatan bagi manajer untuk melakukan tindakan oportunis seperti manajemen laba (earnings management) untuk memaksimalkan kepentingan pribadinya sehingga dapat merugikan para pemegang saham(Jensen dan Mecking, 1976).

\section{Kepemilikan Saham Institusional}

Kepemilikan saham institusional adalah kepemilikan saham suatu perusahaan oleh institusi baik yang bergerak dalam bidang keuangan atau non keuangan atau badan hukum lain. Peran pemegang saham institusional dalam mengawasi kebijakan perusahaan sangat diperlukan untuk menjamin tata kelola perusahaan yang baik. Keefektifan fungsi pengawasan yang diperankan pemegang saham institusional tidak hanya terkait pada konsentrasi kepemilikan tetapi juga identitas pemegang saham (Gedajlovic dan Shapiro, 2003). Boediono (2005) menyatakan bahwa melalui mekanisme kepemilikan institusional, efektivitas pengelolaan sumber daya perusahaan oleh manajemen dapat diketahui dari informasi yang dihasilkan melalui reaksi pasar atas pengumuman laba. 


\section{Prosedur Audit}

Prosedur audit merupakan serangkain langkah-langkah yang harus dilaksanakan dalam melakukan audit. Namun, dalam prakteknya auditor mengurangi langkah-langkah dalam melakukan audit. Langkah-langkah dalam pengurangan audit dapat dicontoh dengan, mengurangi jumlah sampel dalam audit, melakukan review dangkal terhadap dokumen klien, tidak memperluas pemeriksaan ketika terdapat pos yang dipertanyakan, dan memberikan opini ketika semua prosedur audit belum dilaksanakan secara lengkap. Hal ini disebut dengan penghentian prematur. Standar prosedur audit yaitu: Inspeksi (pemeriksaaan), pengamatan, permintaan keterangan merupakan prosedur audit yang dilakukan dengan meminta keterangan secara lisan dan konfirmasi.

\section{Kualitas Audit}

Kualitas audit adalah hal yang penting karena mencerminkan seberapa baik mutu hasil audit yang diberikan oleh auditor eksternal. Pelaksana audit eksternal adalah pihak luar perusahaan yang independen. Pihak luar perusahaan yang independen adalah akuntan publik yang telah diakui oleh yang berwenang untuk melaksanakan tugas tersebut. Auditing ini bertujuan untuk memberikan pendapat mengenai kewajaran laporan keuangan. Auditor tersebut pada umumnya dibayar oleh manajemen perusahaan yang diperiksa. Auditor eksternal merupakan orang yang independen di luar perusahaan. Auditor eksternal melayani pihak ke tiga yang memerlukan informasi keuangan yang dapat diandalkan. Auditor eksternal fokus pada ketepatan dan kemudahan pemahaman dan kejadian di masa lalu yang dinyatakan dalam laporan keuangan, dan akan memberikan perhatian-perhatian lebih bila kecurangan akan mempengaruhi laporan keuangan secara meterial. Independen auditor eksternal terhadap manajemen dan dewan direksi, baik dalam kenyataan maupun secara mental.

\section{Dewan Komisaris}

Dewan komisaris adalah bagian organ perseroan (seluruh anggota dewan komisaris) yang bertugas untuk melakukan pengawasan dan memastikan bahwa perusahaan melaksanakan good corporate governance. Menurut Sembiring (2005) pengukuran ukuran dewan komisaris menggunakan jumlah anggota dewan komisaris. Dewan komisaris adalah salah satu unsur dari tata kelola perusahaan yang berasal dari mekanisme internal dan dewan komisaris bertanggung jawab kepada pemegang saham dan membantu direksi dalam bekerja, serta merupakan posisi dengan kedudukan tertinggi dalam pelaksanaan Good Corporate Governance. Salah satu fungsi sentral Dewan Komisaris adalah pengawasan terhadap pelaporan keuangan.

\section{Frekuensi Pertemuan Komite Audit}

Komite audit dengan jumlah atau ukuran yang semakin banyak berarti ide akan lebih banyak dan kinerja lebih baik karena adanya kerja sama dari berbagai anggota dan ketua komite audit dalam pekerjaan lapangannya. Untuk mempertahankan independensi, Badan Pengawas Pasar Modal dan Laporan Keuangan (PAPEPAM-LK) (2004) mengeluarkan peraturan tentang Komite Audit yang menyebutkan bahwa komite audit paling kurang terdiri dari 3 (tiga) orang anggota yang berasal dari Komisaris Independen dan pihak dari luar Emiten atau perusahaan publik. Tujuan umum dari pembentukan komite audit, antara lain untuk mengembangkan kualitas pelaporan keuangan. Memastikan bahwa direksi membuat keputusan berdasarkan kebijakan, praktik dan pengungkapan akuntansi, menelaah ruang lingkup dan hasil dari audit internal dan eksternal, dan mengawasi proses pelaporan keuangan. 


\section{Komite Remunerasi}

Komite remunerasi dibentuk untuk memastikan bahwa pengaturan remunerasi mendukung tujuan strategis sebuah bisnis dan memungkinkan perektrutan, motivasi dan retensi para eksekutif senior dan juga mematuhi persyaratan peraturan. Komite remunerasi seharusnya mendelegasikan tanggung jawab untuk menetapkan remunerasi bagi semua direktur eksekutif dan ketua, termasuk hak pensiun dan pembayaran kompensasi. Komite ini juga merekomendasikan dan memantau tingkat dan struktur remunerasi bagi managemen.

\section{Luas Pengungkapan Kompensasi Manajemen Kunci}

Personil manajemen kunci perusahaan adalah orang-orang yang mempunyai kewenangan dan tanggung jawab untuk merencanakan, memimpin dan mengendalikan aktivitas perusahaan, secara langsung maupun tidak langsung, termasuk seluruh anggota Dewan Komisaris dan Direksi perusahaan. Atau dapat dikatakan, personil manajemen kunci perusahaan merupakan manajemen perusahaan yang berada dalam jajaran Top Management. Selain karena merupakan pengungkapan wajib, pengungkapan kompensasi manajemen kunci di Laporan Keuangan dianggap penting karena dapat merepresentasikan pencapaian kinerja suatu perusahaan. Hal ini didukung oleh penelitian Conyon dan He (2011) yang menemukan hubungan positif antara kompensasi eksekutif dengan kinerja perusahaan. Dengan begitu, para pihak eksternal dapat menilai kinerja suatu perusahaan, salah satunya dengan melihat jumlah kompensasi manajemen kunci di Laporan Keuangan.

Hal tersebut dikarenakan pembayaran kompensasi bagi manajemen kunci ditetapkan berdasarkan tingkat kinerja yang dicapai manajemen kunci dalam memenuhi target perusahaan. Sehingga dapat disimpulkan, semakin besar kompensasi yang diberikan kepada manajemen kunci dapat mengindikasikan semakin tinggi pula tingkat pencapaian kinerja manajemen kunci dalam rangka meningkatkan nilai perusahaan. Oleh karena itu, dengan semakin luasnya pengungkapan kompensasi manajemen kunci di Laporan Keuangan, akan semakin meyakinkan investor untuk melakukan investasi di suatu perusahaan.

\section{Kepemilikan Saham Institusional dan Kompensasi Manajemen Kunci}

Jensen dan Meckling (1976) menyatakan bahwa kepemilikan saham institusional memiliki peranan yang sangat penting dalam meminimalisasi konflik keagenan yang terjadi antara manajer dan pemegang saham. Kepemilikan saham institusional adalah kepemilikan saham perusahaan yang dimiliki oleh institusi atau lembaga seperti perusahaan asuransi, bank, perusahaan investasi dan kepemilikan institusi lain (Tarjo, 2008).

Dengan menggabungkan argumen teori agensi dengan konsentrasi kepemilikan institusional, maka dapat dikatakan bahwa kepemilikan pemilik insitusional yang lebih besar atau semakin besar jumlah blockholder, semakin besar kemampuan mereka untuk mengendalikan gaji, pilihan, dan kompensasi total. Kepemilikan institusional sebagai pemegang saham terbanyak perusahaan ingin memastikan bahwa sumber daya dikelola dengan baik jadi jangan sampai ada upaya untuk mengekploitasi atau memanfaatkan sumber daya perusahaan untuk kepentingan pribadi bagi manajemen, misalnya dengan pemberian gaji atau kompensasi yang terlalu tinggi. Pemegang saham besar ini akan menganjurkan perilaku kompensasi yang lebih baik dan mengurangi kompensasi berbasis hasil sebagai persentase dari total kompensasi. Dengan pengawasan yang lebih efektif dari pihak investor institusional tersebut, maka manajemen akan mengungkapkan informasi mengenai kompensasi manajemen kunci secara lebih transparan. 
Kepemilikan saham institusional melakukan fungsi monitoring melalui RUPS. Rapat Umum Pemegang Saham (RUPS) merupakan badan tertinggi yang terdiri atas pemegang saham yang memiliki hak untuk memilih anggota dewan komisaris dan dewan direksi. Kondisi yang terjadi dapat dijadikan suatu motivasi institusional ownership untuk dapat lebih serius dalam melakukan pengawasan atau dalam mengoreksi perilaku manajer dan juga agar dapat memperpanjang jangka waktu dalam berinvestasi. Mekanisme pengawasan ini dapat dilakukan dengan menempatkan dewan ahli yang tidak dibiayai oleh perusahaan sehingga posisi dewan ahli tidak berada pada pengawasan manajer. Dengan ini dewan ahli dapat menjalankan fungsinya secara efektif untuk dapat mengontrol semua tindakan yang dilakukan oleh manager. Bentuk pengawasan lain yang dapat dilakukan oleh dewan ahli adalah dengan memberikan masukan kepada manager untuk dijadikan pertimbangan dalam menjalankan usaha dan melalui Rapat Umum Pemegang Saham (RUPS). Jadi, semakin tinggi presentase saham yang dimiliki oleh institusional ownership dapat menyebabkan pengawasan yang lebih efektif karena dapat mengendalikan perilaku oportunistik manajer dan juga dapat mengurangi agency cost.

Penelitian Wulandari et al., (2014) mendapatkan bahwa kepemilikan saham institusional memiliki pengaruh signifikan positif terhadap integritas luas pengungkapan kompensasi manajemen kunci. Hal ini juga didukung penelitian Wang (2006) yang menyatakan bahwa kepemilikan saham institusional berpengaruh terhadap luas pengungkapan kompensasi manajemen kunci. Penelitian Ali et al (2007) juga menyimpulkan bahwa kepemilikan saham institusional berpengaruh terhadap luas pengungkapan kompensasi manajemen kunci. Berdasarkan uraian di atas, maka diambil hipotesis sebagai berikut:

\section{H1 : Kepemilikan Saham Institusional berpengaruh positif terhadap luas pengungkapan kompensasi manajemen kunci di Laporan Keuangan}

\section{Kualitas Audit dan Kompensasi Manajemen Kunci}

Auditor dalam mengaudit laporan keuangan memberikan usulan laporan keuangan supaya lebih transparan dan supaya pihak luar bisa menguji. Informasi mengenai penggunaan manajemen kunci dianggap sangat penting, karena informasi tersebut dibutuhkan bagi pihak luar untuk menilai perusahaan tersebut sudah dikelola dengan baik atau belum. Pengukuran kualitas audit dapat ditentukan melalui ukuran KAP yang melakukan audit di perusahaan tersebut. Perusahaan yang diaudit oleh KAP besar (KAP Big 4) diharapkan dapat mengungkapkan informasi keuangan dengan lebih luas karena KAP Big 4 memiliki insentif untuk melindungi reputasi KAP-nya sehingga dapat lebih transparan dan mendorong luasnya pengungkapan kompensasi manajemen kunci di laporan keuangan. Informasi mengenai pengungkapan kompensasi manajemen dianggap penting bagi pihak luaruntuk menilai apakah perusahaan telah dikelola dengan baik, jangan sampai manajer menerima gaji yang lebih besar daripada yang seharusnya.

Penelitian yang dilakukan Bassert et al. (2007) menunjukkan bahwa apabila kualitas audit suatu perusahaan semakin baik, maka informasi keuangan yang diungkapkan juga akan semakin luas dan pengukuran dari kualitas audit dapat ditentukan melalui ukuran suatu KAP yang telah diberi wewenang untuk melakukan audit pada perusahaan tersebut. Perusahaan yang diaudit oleh KAP besar (KAP Big 4) diharapkan dapat mengungkapkan informasi keuangan dengan lebih luas karena KAP Big 4 memiliki insentif untuk melindungi reputasi KAP-nya sehingga dapat lebih transparan dan mendorong luasnya pengungkapan manajemen kunci di laporan keuangan. 
Penelitian Farahmita (2012) juga menemukan pengaruh positif kualitas audit yang diukur dengan ukuran KAP terhadap luasnya pengungkapan kompensasi manajemen kunci di laporan keuangan. Hal ini juga didukung penelitian Wang dan Chen (2004) yang menyatakan adanya pengaruh positif antara kualitas audit terhadap luas pengungkapan kompensasi manajemen kunci. Penelitian Bassett et al. (2007) menyimpulkan adanya pengaruh positif antara kualitas auditor terhadap luas pengungkapan manajemen kunci. Berdasarkan uraian di atas, maka diambil hipotesis sebagai berikut:

\section{H2 : Kualitas audit berpengaruh positif terhadap luas pengungkapan kompensasi manajemen kunci di Laporan Keuangan.}

\section{Frekuensi Pertemuan Komite Audit dan Kompensasi Manajemen Kunci}

Tugas komite audit berhubungan dengan kualitas laporan keuangan serta kinerja operasional perusahaan, sebab komite audit diharapkan mampu membantu dewan komisaris dalam melaksanakan dan menjalankan tugasnya. Adapun tugas dari komite audit ialah mengawasi setiap proses pelaporan keuangan oleh manajemen. Fungsi dari komite audit yang utama adalah membantu dan memberikan suatu masukkan kepada dewan komisaris tentang beberapa hal yang perlu dilaksanakan oleh direksi, misalnya sebagai berikut: mengimplementasikan prinsip-prinsip tata kelola perusahaan yang baik dan manajemen risiko. Semakin tinggi frekuensi pertemuan komite audit maka semakin besar pengaruhnya dalam menganjurkan luas pengungkapan kompensasi manajemen kunci dalam laporan keuangan perusahaan. Frekuensi pertemuan komite audit merupakan sarana untuk mempertanggungjawabkan fungsi dari komite audit kepada dewan komisaris dan juga kepada perusahaan. Semakin sering komite audit melakukan pertemuan maka semakin banyak hal yang akan dievaluasi, salah satunya adalah kepatuhan perusahaan untuk mematuhi peraturan, termasuk dalam mengungkapkan luas pengungkapan kompensasi manajemen kunci dalam laporan keuangan. Informasi tentang pengungkapan kompensasi manajemen kunci dianggap hal penting karena informasi tersebut dibutuhkan bagi pihak investor untuk menilai apakah perusahaan tersebut telah dikelola dengan baik. Dengan demikian dapat dikatakan frekuensi pertemuan komite audit berpengaruh positif terhadap luas pengungkapan kompensasi manajemen kunci di laporan keuangan.

Sejalan dengan peraturan tersebut, penelitian Zhang et al. (2007) menyebutkan bahwa komite audit yang bertugas dengan efektif dapat mendorong internal control perusahaan menjadi lebih baik. Praktik internal control yang baik diharapkan dapat mendorong kepatuhan perusahaan untuk mematuhi standar akuntansi yang berlaku, salah satunya melalui pengungkapan kompensasi manajemen kunci di laporan keuangan. Hal ini juga didukung penelitian Akmyga dan Mita (2015) yang menyimpulkan bahwa frekuensi pertemuan komite audit berpengaruh positif terhadap luas pengungkapan kompensasi manajemen kunci. Berdasarkan uraian di atas, maka diambil hipotesis sebagai berikut:

\section{H3 : Frekuensi pertemuan komite audit berpengaruh positif terhadap luas pengungkapan kompensasi manajemen kunci di Laporan Keuangan.}

\section{Komite Remunerasi dan Kompensasi Manajemen Kunci}

Komite remunerasi adalah adalah Komite Dewan Komisaris Perusahaan yang dibentuk untuk memenuhi Peraturan Otoritas Jasa Keuangan. Komite Nominasi dan Remunerasi dibentuk oleh Dewan Komisaris dan bertanggung jawab langsung kepada Dewan Komisaris. 
Tugas dari komite remunerasi adalah membantu dewan komisaris untuk mengurus tentang kompensasi semua anggota perusahaan khususnya jajaran manajemen perusahaan. Dewan Komisaris sebagai perwakilan dari pemegang saham akan selalu menjaga kepentingan dari pemegang saham dalam perusahaan. Komite remunerasi yang dibentuk oleh Dewan Komisaris juga termasuk perwakilan dari pemegang saham yang menginginkan seluruh informasi mengenai gaji atau kompensasi yang diterima oleh direksi diketahui oleh para pemegang saham agar pemegang saham dapat mengetahui laporan yang diungkapkan wajar atau tidak jumlah kompensasi manajemen kuncinya, jadi jika laporan mengenai kompensasi manajemen kunci dianggap tidak wajar akan ada tenaga penyesuaian agar laporan tentang pengungkapan kompensasi manajemen kunci yang disajikan lebih transparan.Semakin banyak jumlah anggota komite remunerasi maka menunjukkan bahwa perusahaan memiliki implementasi tata kelola yang baik sehingga proses internal kontrol semakin baik pula termasuk dalam mengungkapkan informasi mengenai kompensasi manajemen kunci. Informasi tentang pengungkapan kompensasi manajemen kunci dianggap hal penting karena informasi tersebut dibutuhkan bagi pihak investor untuk menilai pakah perusahaan tersebut telah dikelola dengan baik. Hal ini juga dapat diketahui bahwa dengan adanya proses internal yang baik akan berdampak pada semakin patuhnya pihak manajemen perusahaan dalam mengungkapkan semakin tingginya luas pengungkapan kompensasi manajemen kunci pada laporan keuangan.

Penelitian Farahmita (2012) menyatakan adanya pengaruh positif antara komite remunerasi terhadap luas pengungkapan kompensasi manajemen kunci di laporan keuangan. Hal ini juga didukung penelitian Akmyga dan Mita (2015) yang menyimpulkan bahwa komite remunerasi berpengaruh positif terhadap luas pengungkapan kompensasi manajemen kunci.

Berdasarkan uraian di atas, maka diambil hipotesis sebagai berikut:

\section{H4 : Komite remunerasi berpengaruh positif terhadap luas pengungkapan kompensasi manajemen kunci di Laporan Keuangan.}

\section{METODA PENELITIAN}

\section{Populasi dan Sampel Penelitian}

Populasi yang digunakan dalam penelitian ini adalah laporan keuangan dari semua perusahaan yang terdaftar di Bursa Efek Indonesia (BEI) periode tahun 2012-2016. Metode purposive sampling digunakan dalam pemilihan sampel dengan metode dengan menentukan kriteria tertentu untuk dijadikan sampel penelitian. Kriteria yang digunakan dalam penelitian ini adalah sebagai berikut:

1. Perusahaan yang telah terdaftar di BEI dari tahun 2012-2016.

2. Laporan keuangan perusahaan dapat diakses dari sumber data

3. Komponen data yang digunakan untuk penelitian lengkap selama periode pengamatan termasuk kepemilikan saham institusional, kualitas audit, frekuensi pertemuan komite audit, komite remunerasi dan luas pengungkapan kompensasi manajemen kunci. 
Prosedur pemilihan sampel secara lengkap dapat dilihat pada tabel 3.1.

Tabel 3.1. Prosedur Pemilihan Sampel

\begin{tabular}{|c|l|c|c|c|c|c|c|}
\hline No & \multicolumn{1}{|c|}{ Keterangan } & 2012 & 2013 & 2014 & 2015 & 2016 & Total \\
\hline 1. & $\begin{array}{l}\text { Perusahaan yang terdaftar } \\
\text { di BEI tahun 2012-2016. }\end{array}$ & 458 & 435 & 457 & 451 & 450 & 2682 \\
\hline 2. & $\begin{array}{l}\text { Laporan Tahunan yang } \\
\text { tidak tersedia dari sumber } \\
\text { data yang digunakan }\end{array}$ & $(57)$ & $(40)$ & $(45)$ & $(51)$ & $(39)$ & $(232)$ \\
\hline 3 & $\begin{array}{l}\text { Perusahaan tidak } \\
\text { memiliki data tentang } \\
\text { komite remunerasi }\end{array}$ & $\begin{array}{c}(320 \\
)\end{array}$ & $(317)$ & $(321)$ & $(251)$ & $(223)$ & $(1432)$ \\
\hline & Total Sampel & 81 & 78 & 91 & 149 & 188 & 587 \\
\hline
\end{tabular}

Sumber: Data sekunder yang diolah

\section{Sumber dan Jenis Data Penelitian}

Jenis data yang digunakan dalam penelitian ini adalah data sekunder. Data sekunder adalah data yang diperoleh dari perantara atau dapat diambil dari data yang sudah ada, sehingga peneliti cukup melakukan pengumpulan data guna untuk bahan penelitian. Data sekunder dalam penelitian ini adalah laporan keuangan perusahaan yang telah terdaftar di BEI pada periode tahun 2012-2016. Dan sumber data pada penelitian ini berasal dari IDX Statistik PIPM Semarang dan situs BEI (www.idx.co.id).

\section{Definisi Operasional dan Pengukuran Variabel}

1. Kepemilikan saham institusional

Merupakan kepemilikan saham oleh pemerintah, institusi keuangan, institusi berbadan hukum, institusi luar negeri, dana perwalian dan institusi lainnya pada akhir tahun (Winanda, 2009). Pada penelitian ini diukur dengan prosentase jumlah kepemilikan saham institusional dalam sebuah perusahaan.

2. Kualitas Audit

Kualitas Audit diukur menggunakan variabel dummy yang diberi kode 1 jika perusahaan di audit oleh KAP yang berafiliasi dengan KAP Big 4 dan 0 jika di audit oleh KAP yang tidak berafiliasi dengan KAP Big 4. KAP lokal yang berafiliasi dengan KAP Big 4 selama periode penelitian yaitu:

a) Hans Tuanakotta Mustofa \& Halim; Osman Ramli Satrio \& Rekan; Osman Bing Satrio \& Rekan berafiliasi dengan Deloitte Touche Tohmatsu (Deloitte).

b) Prasetio, Sarwoko \& Sandjaja Purwantono berafiliasi dengan Ernest \& Young (EY) yang

c) Siddharta \& Widjaja berafiliasi dengan Klynveld Peat Marwick Goerdeler (KPW).

d) Haryanto Sahari \& Rekan. Berafiliasi dengan Pricewaterhouse Coopers (PwC).

3. Frekuensi pertemuan komite audit

Frekuensi pertemuan komite audit diukur dengan jumlah rapat komite audit yang ada dalam sebuah perusahaan dalam setahun. 
4. Komite Remunerasi

Komite remunerasi pada penelitian ini diukur dengan jumlah orang yang menduduki posisi komite remunerasi dalam sebuah perusahaan.

5. Luas Pengungkapan Kompensasi Manajemen Kunci

Luas pengungkapan kompensasi manajemen kunci merupakan tingkat luasnya pengungkapankompensasi manajemen kunci di laporan keuangan perusahaan i pada tahun t. Luasnya pengungkapan diukur dengan menggunakan skor seperti pada penelitian yang sebelumnya dilakukan oleh Farahmita (2012). Skor pengungkapan terbagi lima, yaitu:

1. Skor 0 diberikan apabila perusahaan tidak mengungkapkan kompensasi manajemen kunci di laporan keuangan.

2. Skor 1 diberikan apabila perusahaan hanya menyajikan total kompensasi tanpa keterangan kategori imbalan.

3. Skor 2 diberikan apabila perusahaan mengungkapkan total kompensasi masingmasing komisaris dan direktur.

4. Skor 3 diberikan apabila perusahaan mengungkapkan total kompensasi dengan memberikan deskripsi/kategori imbalan.

5. Skor 4 diberikan apabila perusahaan mengungkapkan total kompensasi dan memberikan rincian sub jumlah per kategori imbalan kerja.

\section{Model Analisis Regresi}

Uji hipotesis dalam penelitian ini adalah analisis regresi linear berganda. Penelitian ini bertujuan untuk dapat mengetahui pengaruh dari satu variabel independen terhadap variabel dependen. Model persamaan regresi dalam penelitian ini sebagai berikut:

$$
\mathrm{LPL}=\beta_{0}+\beta_{1} \mathrm{KI}+\beta_{2} \mathrm{KA}+\beta_{3} \mathrm{FKA}+\beta_{4} \mathrm{KR}+\mathrm{e}
$$

Keterangan:

LPL = Luas Pengungkapan Kompensasi Manajemen Kunci

$\beta_{0} \quad=$ Konstanta

$\beta_{1} \ldots \beta_{4}=$ Nilai beta dari masing-masing variabel independen

$\mathrm{KI}=$ Kepemilikan Saham Institusional

$\mathrm{KA}=$ Kualitas Audit

FKA $=$ Frekuensi pertemuan komite audit

$\mathrm{KR}=$ Komite Remunerasi

$\mathrm{e} \quad=$ Error

\section{HASIL DAN PEMBAHASAN}

\section{Statistik Deskriptif}

Statistik deskriptif pada penelitian ini adalah dari data awal yang berjumlah 587, ternyata ada cukup banyak data yang tidak normal sehingga data normalnya berjumlah menjadi 287. 
Tabel 4.1.

Statistik Deskriptif

\begin{tabular}{|l|r|r|r|r|r|}
\hline & N & Minimum & Maximum & \multicolumn{1}{c|}{ Mean } & Std. Deviation \\
\hline Kep_Inst & 287 & 0,000 & 98,870 & 38,355 & 32,295 \\
Kualitas_Aud & 287 & 0,000 & 1,000 & 0,554 & 0,498 \\
Frek_KA & 287 & 2,000 & 58,000 & 5,996 & 5,457 \\
Kom_Rem & 287 & 1,000 & 8,000 & 3,379 & 0,985 \\
Man_Kunci & 287 & 0,000 & 4,000 & 2,268 & 0,482 \\
Valid N (listwise) & 287 & & & & \\
\hline
\end{tabular}

Sumber: Data sekunder yang diolah

Berdasarkan tabel 4.1 di atas dapat diketahui bahwa kepemilikan institusional memiliki nilai minimum 0,000 , nilai maksimum 98,870 dan rata-ratanya 38,355 dengan standar deviasi sebesar 32,295. Variabel kualitas audit memperoleh nilai minimum 0,000, nilai maksimum 1,000, standart deviasi 0,498 , dan rata-rata sebesar 0.554 artinya rata-rata perusahaan yang menjadi sampel pada penelitian ini diaudit oleh KAP Big Four. Frekuensi rapat KA (komite audit) memiliki nilai minimum 2 dan maksimum 58 dengan rata-rata 5,996. Hal ini menunjukkan bahwa dalam secara rata-rata perusahaan mengadakan rapat antara 5-6 kali dalam satu tahun.

Variabel komite remunerasi rata-ratanya sebesar 3,379, nilai minimum 1 dan maksimum 8. Artinya perusahaan yang menjadi sampel penelitian ini secara rata-rata memiliki komite remunerasi sekitar 3-4 orang.

Nilai minimum untuk variabel luas pengungkapan manajemen kunci sebesar 0 dan maksimum sebesar 4 dengan rata-rata sebesar 2,268. Artinya, secara rata-rata skor dalam mengkapkan kompensasi manajemen kunci berada antara 2-3. Skor 2 diberikan apabila perusahaan mengungkapkan total kompensasi masing-masing komisaris dan direktur. Skor 3 diberikan apabila perusahaan mengungkapkan total kompensasi dengan memberikan deskripsi/kategori imbalan.

\section{Uji Normalitas}

Tabel 4.2 menampilkan hasi uji normalitas data. Berdasarkan pada tabel 4.2, dapat diketahui bahwa ternyata hasil pengujian untuk normalitas akhir dapat dilihat dari nilai Kolmogorof-Smirnov sig. sebesar 0,200 > 0,05 dapat dikatakan bahwa data pada penelitian ini normal.

Tabel 4.2.

\section{Hasil Uji Normalitas}

\begin{tabular}{|l|r|r|r|r|r|r|}
\hline & \multicolumn{3}{|c|}{ Kolmogorov-Smirnov $^{\mathrm{a}}$} & \multicolumn{3}{c|}{ Shapiro-Wilk } \\
\cline { 2 - 7 } & Statistic & \multicolumn{1}{c|}{ df } & \multicolumn{1}{c|}{ Sig. } & Statistic & \multicolumn{1}{c|}{ df } & \multicolumn{1}{c|}{ Sig. } \\
\hline $\begin{array}{l}\text { Unstandardized } \\
\text { Residual }\end{array}$ &, 046 & 287 &, $200^{*}$ &, 985 & 287 &, 004 \\
\hline
\end{tabular}

Sumber: Data sekunder yang diolah

\section{Uji Multikolinearitas}

Berdasarkan hasil dari tabel 4.3 dapat diketahui bahwa hasil pengujian untuk multikolinearitas memiliki nilai Tolerance untuk masing-masing variabel independen $>0,1$ 
dan untuk nilai VIF $<10$ sehingga dapat dikatakan tidak terjadi multikolinearitas pada penelitian ini.

Tabel 4.3.

Hasil Pengujian Multikolinearitas

\begin{tabular}{|ll|r|r|}
\hline \multirow{2}{*}{ Model } & \multicolumn{2}{|c|}{ Collinearity Statistics } \\
\cline { 2 - 4 } & Tolerance & \multicolumn{1}{|c|}{ VIF } \\
\hline 1 & (Constant) & & \\
& KA &, 910 & 1,099 \\
FKA &, 959 & 1,042 \\
KR &, 794 & 1,260 \\
KI &, 865 & 1,156 \\
\hline
\end{tabular}

\section{Uji Autokorelasi}

Berdasarkan tabel 4.4 dapat diketahui bahwa ternyata hasil pengujian untuk autokorelasi sebesar 1,837 berada diantara 1,5 dan 2,5 artinya tidak terjadi autokorelasi pada penelitian ini.

Tabel 4.4.

Hasil Pengujian Autokorelasi

\begin{tabular}{|l|r|r|r|r|r|}
\hline Model & \multicolumn{1}{|c|}{$\mathrm{R}$} & R Square & $\begin{array}{c}\text { Adjusted R } \\
\text { Square }\end{array}$ & $\begin{array}{l}\text { Std. Error of } \\
\text { the Estimate }\end{array}$ & $\begin{array}{l}\text { Durbin- } \\
\text { Watson }\end{array}$ \\
\hline 1 &, $750^{\mathrm{a}}$ &, 562 &, 556 &, 29688 & 1,837 \\
\hline
\end{tabular}

Sumber: Data sekunder yang diolah

\section{Uji Heteroskedastisitas}

Berdasarkan pada tabel 4.5. dapat diketahui bahwa ternyata hasil pengujian heteroskedastisitas untuk masing-masing variable independen memiliki nilai signifikansi di atas 0,05 sehingga dengan demikian dapat dikatakan tidak terjadi heteroskedastisitas.

Tabel 4.5.

Hasil Pengujian Heteroskedastisitas

Coefficients $^{\text {a }}$

\begin{tabular}{|c|c|c|c|c|c|c|}
\hline \multirow{2}{*}{\multicolumn{2}{|c|}{ Model }} & \multicolumn{2}{|c|}{$\begin{array}{c}\text { Unstandardized } \\
\text { Coefficients }\end{array}$} & \multirow{2}{*}{$\begin{array}{c}\begin{array}{c}\text { Standardized } \\
\text { Coefficients }\end{array} \\
\text { Beta }\end{array}$} & \multirow[b]{2}{*}{$\mathrm{t}$} & \multirow[b]{2}{*}{ Sig. } \\
\hline & & B & Std. Error & & & \\
\hline \multirow[t]{5}{*}{1} & (Constant) &, 049 & ,010 & & 5,082 &, 000 \\
\hline & KA &,- 001 &, 005 &,- 017 &,- 267 & ,790 \\
\hline & FKA &,- 001 &, 000 &,- 105 & $-1,731$ &, 085 \\
\hline & $\mathrm{KR}$ & $3,575 \mathrm{E}-5$ & ,002 & ,001 &, 015 & ,988 \\
\hline & $\mathrm{KI}$ & $-2,860 \mathrm{E}-5$ &, 000 &,- 025 &,- 397 & ,692 \\
\hline
\end{tabular}

Sumber: Data sekunder yang diolah 


\section{Pengujian Hipotesis}

Pengujian hipotesis adalah langkah terakhir yang harus dilakukan untuk mengetahui pengaruh variabel independen terhadap variabel dependen. Pengujian dilakukan dengan menggunakan uji t dengan hasil sebagai berikut:

Tabel 4.6.

\section{Hasil Analisis Regresi}

\begin{tabular}{|c|c|c|c|c|c|c|}
\hline \multirow{2}{*}{\multicolumn{2}{|c|}{ Model }} & \multicolumn{2}{|c|}{$\begin{array}{c}\text { Unstandardized } \\
\text { Coefficients }\end{array}$} & \multirow{2}{*}{$\begin{array}{c}\begin{array}{c}\text { Standardized } \\
\text { Coefficients }\end{array} \\
\text { Beta }\end{array}$} & \multirow[b]{2}{*}{$\mathrm{t}$} & \multirow[b]{2}{*}{ Sig. } \\
\hline & & B & Std. Error & & & \\
\hline 1 & (Constant) & 1,184 & ,078 & & 15,155 &, 000 \\
\hline & $\mathrm{KI}$ & ,002 & ,001 & ,129 & 3,036 & ,003 \\
\hline & $\mathrm{KA}$ & ,348 & 037 & ,389 & 9,430 &, 000 \\
\hline & FKA &,- 008 & ,003 &,- 093 & $-2,309$ & ,022 \\
\hline & KR & ,258 & ,020 & ,571 & 12,910 &, 000 \\
\hline
\end{tabular}

Sumber: Data sekunder yang diolah

\section{Hipotesis Pertama}

Dari tabel 4.6. diketahui ternyata nilai signifikansi $t$ untuk variabel kepemilikan institusional sebesar $0,003 / 2=0,0015<0,05$ dengan beta koefisien +0.002 sehingga artinya hipotesis pertama pada penelitian ini diterima. Jadi kepemilikan institusional berpengaruh positif terhadap luas pengungkapan kompensasi manajemen kunci.

\section{Hipotesis Kedua}

Dari tabel 4.6. diketahui ternyata nilai signifikansi t untuk variabel kualitas audit sebesar $0,000 / 2=0,000<0,05$ dengan koefisien beta +0.348 sehingga artinya hipotesis kedua pada penelitian ini diterima. Jadi kualitas audit berpengaruh positif terhadap luas pengungkapan kompensasi manajemen kunci.

\section{Hipotesis Ketiga}

Dari tabel 4.6. diketahui ternyata nilai signifikansi t untuk variabel frekuensi pertemuan komite audit sebesar 0,022/2=0.011 < 0,05 tetapi koefisien beta -0.008 sehingga artinya hipotesis ketiga pada penelitian ini ditolak karena berbeda arah. Jadi frekuensi pertemuan komite audit berpengaruh negatif terhadap luas pengungkapan kompensasi manajemen kunci.

\section{Hipotesis Keempat}

Dari tabel 4.6. diketahui ternyata nilai signifikansi t untuk variabel komite remunerasi sebesar $0,000 / 2=0.000<0,05$ dengan beta koefisien regresi +0.258 sehingga artinya hipotesis keempat pada penelitian ini diterima. Jadi komite remunerasi berpengaruh positif terhadap luas pengungkapan kompensasi manajemen kunci.

\section{PEMBAHASAN}

\section{Kepemilikan Institusional dan Pengungkapan Kompensasi Manajemen Kunci}

Berdasarkan hasil analisis diketahui bahwa nilai signifikansi $t$ untuk variabel kepemilikan institusional dibawah 0,05 dengan koefisien beta positif sehingga artinya 
kepemilikan istitusional berpengaruh positif terhadap luas pengungkapan kompensasi manajemen kunci.

Dengan menggabungkan argumen teori agensi dengan konsentrasi kepemilikan institusional, maka dapat dikatakan bahwa kepemilikan pemilik institusional yang lebih besar atau semakin besar jumlah blockholder, semakin besar kemampuan mereka untuk mengendalikan gaji, pilihan dan kompensasi total (Wang, 2006). Kepemilikan institusional sebagai pemegang saham terbanyak perusahaan ingin memastikan bahwa sumber daya dikelola dengan baik jadi jangan sampai ada upaya untuk mengekploitasi atau memanfaatkan sumber daya perusahaan untuk kepentingan pribadi bagi manajemen, misalnya dengan pemberian gaji atau kompensasi yang terlalu tinggi. Pemegang saham besar ini akan menganjurkan perilaku kompensasi yang lebih baik dan mengurangi kompensasi berbasis hasil sebagai persentase dari total kompensasi. Dengan pengawasan yang lebih efektif dari pihak investor insitusional tersebut, maka manajemen akan mengungkapkan informasi mengenai kompensasi manajemen kunci secara lebih transparan.

Kepemilikan institusional melakukan fungsi monitoring melalui RUPS. Rapat Umum Pemegang Saham (RUPS) merupakan badan tertinggi yang terdiri atas pemegang saham yang memiliki hak untuk memilih anggota dewan komisaris dan dewan direksi. Kondisi ini dapat menjadikan institusional ownership menjadi termotivasi untuk dapat lebih serius dalam mengawasi dan mengoreksi perilaku manajer dan memperpanjang jangka waktu investasi. Mekanisme pengawasan ini dapat dilakukan dengan menempatkan dewan ahli yang tidak dibiayai oleh perusahaan sehingga posisi dewan ahli tidak berada pada pengawasan manajer. Dengan ini dewan ahli dapat menjalankan fungsinya secara efektif untuk dapat mengontrol semua tindakan yang dilakukan oleh manager. Bentuk pengawasan lain yang dapat dilakukan oleh dewan ahli adalah dengan memberikan masukan kepada manager untuk dijadikan pertimbangan dalam menjalankan usaha dan melalui Rapat Umum Pemegang Saham (RUPS). Jadi, semakin tinggi presentase saham yang dimiliki oleh institusional ownership dapat menyebabkan pengawasan yang lebih efektif karena dapat mengendalikan perilaku oportunistik manajer dan juga dapat mengurangi agency cost.

Hasil ini didukung oleh penelitian yang dilakukan oleh Wulandari dan Budiartha (2014) mendapatkan bahwa kepemilikan saham institusional memiliki pengaruh signifikan positif terhadap integritas luas pengungkapan kompensasi manajemen kunci. Hasil ini juga didukung penelitian Wang (2006) dan Ali et al (2007) yang menyatakan bahwa kepemilikan institusional berpengaruh terhadap luas pengungkapan kompensasi manajemen kunci.

\section{Kualitas Audit dan pengungkapan kompensasi manajemen kunci}

Berdasarkan hasil analisis diketahui bahwa nilai signifikansi t untuk variabel kualitas audit dibawah 0,05 dengan koefisien beta positif sehingga artinya kualitas audit berpengaruh positif terhadap luas pengungkapan kompensasi manajemen kunci.

Auditor dalam mengaudit laporan keuangan memberikan usulan laporan keuangan supaya lebih transparan dan supaya pihak luar bisa menguji. Informasi mengenai penggunaan manajemen kunci dianggap sangat penting, karena informasi tersebut dibutuhkan bagi pihak luar untuk menilai perusahaan tersebut sudah dikelola dengan baik atau belum. Pengukuran kualitas audit ditentukan melalui ukuran KAP yang mengaudit perusahaan tersebut. Perusahaan yang diaudit oleh KAP besar (KAP Big 4) diharapkan dapat mengungkapkan informasi keuangan dengan lebih luas karena KAP Big 4 memiliki insentif untuk melindungi reputasi KAP-nya sehingga dapat lebih transparan dan mendorong luasnya pengungkapan kompensasi manajemen kunci di laporan keuangan. Informasi mengenai pengungkapan kompensasi manajemen dianggap penting bagi pihak luar untuk menilai apakah perusahaan 
telah dikelola dengan baik, jangan sampai manajer menerima gaji yang lebih besar daripada yang seharusnya.

Penelitian yang dilakukan oleh Bassert et al. (2007) menunjukkan bahwa apabila kualitas audit suatu perusahaan semakin baik, maka informasi keuangan yang diungkapakan juga akan semakin luas dan pengukuran dari kualitas audit dapat ditentukan melalui ukuran suatu KAP yang telah diberi wewenang untuk melakukan audit pada perusahaan tersebut. Perusahaan yang diaudit oleh KAP besar (KAP Big 4) diharapkan dapat mengungkapkan informasi keuangan dengan lebih luas karena KAP Big 4 memiliki insentif untuk melindungi reputasi KAP-nya sehingga dapat lebih transparan dan mendorong luasnya pengungkapan manajemen kunci di laporan keuangan.

Hasil ini didukung oleh penelitian yang dilakukan oleh Farahmita (2012) yang menyatakan bahwa pengaruh positif kualitas audit yang diukur dengan ukuran KAP terhadap luasnya pengungkapan kompensasi manajemen kunci di laporan keuangan. Hasil ini juga didukung penelitian Bassett et al (2007) yang menemukan pengaruh positif kualitas audit terhadap luas pengungkapan kompensasi manajemen kunci.

\section{Pertemuan Komite Audit dan pengungkapan kompensasi manajemen kunci}

Berdasarkan hasil analisis diketahui bahwa nilai signifikansi t untuk variabel frekuensi rapat komite audit dibawah 0,05 tetapi koefisien beta negatif sehingga artinya frekuensi rapat komite audit berpengaruh negatif terhadap luas pengungkapan kompensasi manajemen kunci.

Tugas komite audit berhubungan dengan kualitas laporan keuangan serta kinerja operasional perusahaan, sebab komite audit diharapkan mampu membantu dewan komisaris dalam melaksanakan dan menjalankan tugasnya. Adapun tugas dari komite audit ialah mengawasi setiap proses pelaporan keuangan oleh manajemen. Fungsi dari komite audit yang utama adalah membantu dan memberikan suatu masukkan kepada dewan komisaris tentang beberapa hal yang perlu dilaksanakan oleh direksi, misalnya sebagai berikut: mengimplementasikan prinsip-prinsip tata kelola perusahaan yang baik dan manajemen risiko. Semakin tinggi frekuensi rapat komite audit maka semakin besar pengaruhnya dalam menganjurkan luas pengungkapan kompensasi manajemen kunci dalam laporan keuangan perusahaan. Frekuensi pertemuan komite audit adalah sarana untuk mendiskusikan hal-hal penting berkaitan dengan pelaporan keuangan dan pengungkapan yang diperlukan. Semakin sering komite audit melakukan pertemuan maka semakin banyak hal yang akan dievaluasi, salah satunya adalah kepatuhan perusahaan untuk mematuhi peraturan, termasuk dalam mengungkapkan luas pengungkapan kompensasi manajemen kunci dalam laporan keuangan. Informasi tentang pengungkapan kompensasi manajemen kunci dianggap hal penting karena informasi tersebut dibutuhkan bagi pihak investor untuk menilai apakah perusahaan tersebut telah dikelola dengan baik.

Hasil analisis regresi menunjukkan hal yang sebaliknya. Hubungan negatif antara jumlah pertemuan Komite Audir dan pengungkapan kompensasi manajemen kunci menunjukkan bahwa semakin sering komite audit melakukan pertemuan justru pengungkapan kompensasi menjadi semakin terbatas. Dilihat dari nilai statistik deskriptifnya, nilai rata-rata untuk frekuensi pertemuan rapat komite audit sebesar 5.996. artinya, dalam setahun Komite Audit hanya 5-6 kali mengadakan rapat. Tentu ini angka ini sangat sedikit sekali mengingat banyaknya permasalahan yang harus ditangani dalam pelaporan keuangan dan pengungkapannya. Dengan rapat yang sangat sedikit sulit diharapkan Komite Audit menjalankan fungsinya secara efektif. 


\section{Komite Remunerasi dan Pengungkapan Kompensasi Manajemen Kunci}

Berdasarkan hasil analisis diketahui bahwa nilai signifikansi t untuk variabel komite remunerasi dibawah 0,05 dengan koefisien beta positif, sehingga artinya komite remunerasi berpengaruh positif terhadap luas pengungkapan kompensasi manajemen kunci.

Komite remunerasi adalah Komite Dewan Komisaris Perusahaan yang dibentuk untuk memenuhi Peraturan Otoritas Jasa Keuangan. Komite Nominasi dan Remunerasi dibentuk oleh Dewan Komisaris dan bertanggung jawab langsung kepada Dewan Komisaris.

Tugas dari komite remunerasi adalah membantu dewan komisaris untuk mengurus tentang kompensasi semua anggota perusahaan khususnya jajaran manajemen perusahaan. Dewan Komisaris sebagai perwakilan dari pemegang saham akan selalu menjaga kepentingan dari pemegang saham dalam perusahaan. Komite remunerasi yang dibentuk oleh Dewan Komisaris juga termasuk perwakilan dari pemegang saham yang menginginkan seluruh informasi mengenai gaji atau kompensasi yang diterima oleh direksi diketahui oleh para pemegang saham agar pemegang saham dapat mengetahui laporan yang diungkapkan wajar atau tidak jumlah kompensasi manajemen kuncinya, jadi jika laporan mengenai kompensasi manajemen kunci dianggap tidak wajar akan ada tenaga penyesuaian agar laporan tentang pengungkapan kompensasi manajemen kunci yang disajikan lebih transparan. Semakin banyak jumlah anggota komite remunerasi maka menunjukkan bahwa perusahaan memiliki implementasi tata kelola yang baik sehingga proses internal kontrol semakin baik pula termasuk dalam mengungkapkan informasi mengenai kompensasi manajemen kunci. Informasi tentang pengungkapan kompensasi manajemen kunci dianggap hal penting karena informasi tersebut dibutuhkan bagi pihak investor untuk menilai pakah perusahaan tersebut telah dikelola dengan baik. Hal ini juga dapat diketahui bahwa dengan adanya proses internal yang baik akan berdampak pada semakin patuhnya pihak manajemen perusahaan dalam mengungkapkan semakin tingginya luas pengungkapan kompensasi manajemen kunci pada laporan keuangan.

Hasil ini didukung oleh penelitian yang dilakukan oleh Farahmita (2012) menyatakan adanya pengaruh positif antara komite remunerasi terhadap luas pengungkapan kompensasi manajemen kunci di laporan keuangan. Hasil ini juga didukung penelitian Akmyga dan Mita (2015) yang menyimpulkan bahwa komite remunerasi berpengaruh positif terhadap luas pengungkapan kompensasi manajemen kunci.

\section{SIMPULAN}

Dari hasil penelitian yang telah dilakukan, maka kesimpulan yang dapat diambil dari penelitian ini adalah :

1. Kepemilikan saham institusional berpengaruh terhadap luas pengungkapan kompensasi manajemen kunci. Hasil ini didukung oleh penelitian yang dilakukan oleh Wulandari dan Budiartha (2014).

2. Kualitas audit berpengaruh terhadap luas pengungkapan kompensasi manajemen kunci. Hasil ini didukung oleh penelitian yang dilakukan oleh Farahmita (2012).

3. Frekuensi pertemuan komite audit berpengaruh terhadap luas pengungkapan kompensasi manajemen kunci. Hasil ini didukung oleh penelitian yang dilakukan oleh Akmyga dan Mita (2015).

4. Komite remunerasi berpengaruh terhadap luas pengungkapan kompensasi manajemen kunci. Hasil ini didukung penelitian Akmyga dan Mita (2015). 


\section{DAFTAR PUSTAKA}

Akmyga, S.F., dan Mita, A. Farah.2015.Pengaruh Struktur Corporate Governance Dan Kualitas Audit Terhadap Luas Pengungkapan Kompensasi Manajemen Kunci Di Laporan Keuangan. Jurnal Akuntansi dan Keuangan Indonesia, Vol 12, No 1.

Ali, C.B., T. Samir, and M.G. Summa. 2007. Disclosure Quality and Ownership Structure: Evidence from the French Stock Market.

Anderson dan B. 2003. An empirical examination of the role of the CEO and the compensation committee in structuring executive pay. Journal of Banking \& Finance 27, 2003, 1323-1348

Astasari, K G Astri. 2015. Pengaruh Struktur Kepemilikan, Ukuran Komite Audit dan Kualitas Audit Terhadap Luas Pengungkapan Kompensasi Manajemen Kunci di Laporan Keuangan [Effects of Ownership Structure and Audit Committee Size on the Disclosure of Executive Management Compensation in Financial Statements]. Jurnal Manajemen, Vol 10, No 2, 2 September 2015.

Bassett, M., P. S. Koh, and I. Tutticci. 2007. The Association between Employee Stock Option Disclosures and Corporate Governance: Evidence from an Enhanced Disclosure Regime. The British Accounting Review, 39 (4), 303-322.

Bebchuk, L.A., and J.M. Fried. 2003. Executive Compensation As An Agency Problem. Journal of Economic Perspectives, Vol 17, Num 3, 2003, Pages 71-92.

Boediono.2005. Kualitas Laba: Studi Pengaruh Mekanisme Corporate Governance dan Dampak Manajemen Laba Dengan Menggunakan Analisis Jalur. SNA VIII, Solo, 15-16 September, 2005.

Christiawan dan T. 2009.Kepemilikan Manajeral:Kebijakan Hutang, Kinerja dan Nilai Perusahaan. Jurnal Akuntansi dan Keuangan, Vol 9, No 1, Mei 2007: 1-8.

Clarkson MJ, Cardoso MJ, Ridgway GR, Modat M, Leung KK, Rohrer JD, Fox NC, Ourselin S. 2011. A comparison of voxel and surface based cortical thickness estimation methods.Aug 1;57(3):856-65. doi: 10.1016

Core, J.E. and D.F. Larcker. 2002. Performance Consequences of Mandatory Increase in ExecutiveStock Ownership.Journal of Financial Economics 64: 317-340

Conyon, M. and L. He. 2011. Executive Compensation and Corporate Governance in China. Cornell University ILR School.

Dahawy.2009.Perbedaan Tingkat Pengungkapan Antara Perusahaan Asing dan Domestik Dengan Adanya Konvergensi IFRS.Modus Vol 27. (I): 53-64, 2015

Diyah dan W. 2009. Pengaruh Struktur Kepemilikan Terhadap Nilai Perusahaan: Keputusan Keuangan Sebagai Variabel Intervening.Jurnal Ekonomi Bisnis \& Akuntansi Ventura, Vol 12, No 1, April 2009, Hal 71-86.

Farahmita, A. 2012. Pengaruh Struktur Corporate Governance terhadap Pengungkapan Kompensasi Manajemen Kunci diLaporan Keuangan: Studi atas Revisi PSAK No. 7 (2010). Working Paper, Universitas Indonesia.

Gedajlovic, E., dan Shapiro, Daniel. 2003. The Chinese Family Firm As A Multinational Enterprise. The International Journal of Organizational Analysis, Vol. 11 No 2, 2003, pp 105-122. 
Ghozali, I.2016. Aplikasi Analisis Multivariete dengan Program IBM. SPSS 21. Semarang: Badan Penerbit Universitas Diponegoro

Hong, B, Z.F.L dan D. Minor. 2015. Corporate Governance and Executive Compensation for Corporate Social Responsibility. Forthcoming, Journal of Business Ethics.

Jensen, M.C., and W.H. Meckling. 1976. Theory of the Firm: Managerial Behavior, Agency Costs and Ownership Structure. Journal of Financial Economics (JFE), Vol. 3, No. 4, pp 305-360, 1976

Lee. 2008. Randomized experiments from non-random selection in U.S. House elections. Journal of Econometrics 142: 2008, 675-697

Mughni, R.H dan N. Cahyonowati. 2015. Pengaruh Karakteristik Komite Audit dan Kualitas Audit Terhadap Manajemen Laba. Vol. 4, No. 1, 2015, Hal. 1-15.

Nugrahanti, Y. 2014. Pengaruh Audit Tenure, Spesialisasi Kantor Akuntan Publik dan Ukuran Perusahaan Terhadap Kualitas Audit. Diponegoro Journal of Accounting 3 (3): $1-9$.

Permanasari.2010. Pengaruh Kepemilikan Manajemen, Kepemilikan Institusional, dan Corporate Social Responsibility Terhadap Nilai Perusahaan. Fakultas EkonomiUniversitas Diponegoro Semarang.

Pukthuanthong et al.2014.A Protocol for Factor Identification.Department of FinanceUniversity of Missouri Columbia.

Salvatore, D.2005. Managerial Economics. Fifth Edition. Singapore

Sembiring. 2005. Karakteristik Perusahaan dan Pengungkapan Tanggung Jawab Sosial:Study Empiris Pada Perusahaan Yang Tercatat di Bursa Efek Jakarta. SNA VIII, Solo, 15-16 September, 2005.

Shleifer dan V.2012.Neglected risks, Financial Innovation, and Financial Fragility. Journal of Financial Economics 104: 2012, 452-468.

Suaryana.2005.Pengaruh Komite Audit Terhadap Kualitas Laba. SNA VIII, Solo, 15-16 September, 2005.

Sujono dan S.U. 2007. Pengaruh Struktur Kepemilikan Saham, Leverage, Faktor Intern dan Faktor Ekstern terhadap Nilai Perusahaan. Jurnal Manajemen dan Kewirausahan. Vol. 9. No 1. Maret 2007: 41-48

Tarjo.2008.Pengaruh Konsentrasi Kepemilikan Institusional dan Leverage Terhadap Manajemen Laba, Nilai Pemegang Saham Serta Cost Of Equity Capital.Universitas Trunojoyo Bangkalan Madura.

Wang, D. 2006. Founding Family Ownership and earnings Quality. Journal of Accounting Research 44 (3): 619-656.

Weston, J.Fred \& Eugene F Brigham. 2000. Manajemen Keuangan : Jilid 1. Penerbit Salemba Empat. Jakarta

Wulandari, N.P., Yani; Budiartha, I Ketut. 2014. Pengaruh Struktur Kepemilikan, Komite Audit, Komisaris Independen Dan Dewan Direksi Terhadap Integritas Laporan Keuangan. E-Jurnal Akuntansi Universitas Udayana 7.3: 2014, 574-586.

Zhang, Y., J. Zhou, and N. Zhou. 2007. Audit committee quality, auditor independence, and internal control weaknesses. Journal of Accounting and Public Policy26 (3): 300-327. 